Отже, визначена система виховної роботи з формування громадянськості студентської молоді у вищій школі повною мірою розкриває особливості й зміст технології громадянського виховання в навчально-виховному процесі вищого навчального закладу.

\title{
Література
}

1. Борищевський М. Громадянська спрямованість як міра соціальної відповідальності особистості / М. Борищевський // Педагогічна та психологічні науки в Україні. - К. : Педагогічна думка, 2007. - Т. 3. - С. 93-102. 2. Виховання громадянина : Сутність громадянського виховання [П. Ігнатенко, В. Поплужний, Н. Косарєва, Л. Крицька] // Шкільна бібліотека. - 2003. - №8. - С. 3 19. 3. Ортинський В. Педагогіка вищої школи : навч. посіб. [для студ.вищ.навч.закл.] / В. Ортинський. - К. : Центр учбової літератури, 2009. - 472 с. 4. Панфилова А. Инновационные педагогические технологии : Активное обучение : [учеб. пособие для студ. высш. учеб. заведений] / А. Панфилова. - М. : Издательский центр «Академия», 2009. - 192 с. 5. Сігова А. Педагогічні умови формування громадянської позиції студентської молоді : автореф. на здобуття наук. ступеня канд. пед. наук : спец. 13.00.07 «Теорія і методика виховання» / А. Сігова. - Луганськ, 2008. - 20 с. 6. Сопівник I. Формування громадянськості студентів вищих аграрних навчальних закладів : автореф. на здобуття наук. ступеня канд. пед. наук : спец. 13.00.07 «Теорія і методика виховання» / I. Сопівник. - Тернопіль, 2006. -22 с.

УДК 378:811.111(073)

О. В. Хоменко, кандидат пед. наук, доиент, Київський національний університет технологій та дизайну

\section{МОВА МІЖНАЦІОНАЛЬНОГО СПІЛКУВАННЯ ЯК ЕКОНОМІЧНА КАТЕГОРІЯ}

Хоменко О. В. Мова міжнаціонального спілкування як економічна категорія.

У статті йдеться про взаємовплив економіки та мови міжнаціонального спілкування у сучасному глобалізованому світі, про правомірність віднесення lingua franca до економічної категоріі.

Ключові слова: lingua franca, ідеологічна конвергенція, мовний бар’єр, економічна категорія.

Хоменко А. В. Язык межнационального общения как экономическая категория.

В статье речь идет о взаимовлиянии экономики и языка межнационального общения в современном глобализированном мире, о правомерности отнесения lingua franca к экономической категории.

Ключевые слова: lingua franca, идеологическая конвергенция, языковой барьер, экономическая категория.

Khomenko O. Lingua franca as the economic category.

The paper dwells on the reciprocal impact of economy and lingua franca in today's globalized world. Besides the author underscores the legitimacy of attributing the lingua franca to the economic category.

Key words: lingua franca, ideological convergence, language barriers, economic category.

Сучасний світ вступив в епоху глобалізації. Глобалізація в широкому значенні слова - це процес становлення єдиного світу [12]. За Стенлі Фішером (Stanley Fisher), глобалізація - не просто економічний феномен, вона полягає в поступовому формуванні єдиного економічного, інформаційного і культурного простору, «зменшуючи тим самим розміри земної кулі». Одним із найбільш помітних виявів глобалізації є ідеологічна конвергенція, тобто однакова оцінка переваг ринкового шляху розвитку економіки, інакше кажучи, досягнення «глобального однодумства» [6].

Ідеологічна конвергенція зумовлює усунення географічних, політичних та економічних бар'єрів. Натомість з'являється бар'єр мовний. Одним із чинників подолання його є, на нашу думку, становлення мови міжнаціонального спілкування (lingua franca) і оволодіння нею. Аналіз взаємовпливу lingua franca і глобалізованої економіки і $є$ метою нашої статті. 
Досягнення мети можливе за умови реалізації таких завдань: 1) визначити чинники, які впливають на вибір лінгва франка; 2) показати вплив мови міжнаціонального спілкування на економіку країн.

Аналіз фахової літератури 3 різних галузей наук, зокрема економіки, соціології, політології, лінгвістики, методики навчання іноземних мов тощо дозволив нам визначити чинники, які впливають на вибір мови міжнаціонального спілкування в сучасному глобалізованому світі. Спробуємо деталізувати їх.

У нашому дослідженні вже йшлося про те, що одним із основних чинників, які зумовлюють становлення лінгва франка, є політико-економічна могутність тієї чи іншої держави. Британський колоніалізм та американське економічне домінування зробили англійську мову популярною в усіх регіонах світу і вивели їі на рівень лінгва франка мови міжнаціонального спілкування. У результаті цього, як показує практика розвитку і функціонування менеджменту, в глобалізованому світі досить чітко викристалізувалось розуміння важливості володіння англійською мовою, за В. Черенковим (2011), «для успішного розвитку міжнародних бізнес-комунікацій, в першу чергу, на мікро- і мезорівні глобального маркетингового середовища. Не менш як 3/4 усіх міжнародних бізнескомунікацій здійснюється саме англійською мовою».

Наступним чинником, який кардинально змінив ситуацію на користь англійської мови, ми, слідом за Н. Черенковою (2011), уважаємо тектонічні геополітичні й економічні зрушення світової цивілізації (термінологія Н. Черенкової,) наприкінці 20 століття - розпад Радянського Союзу та всеохоплювальну глобалізаџію. У результаті цього російська мова поступилася англійській не лише у сфері бізнесу, але й, певною мірою, перестала відігравати роль лінгва франка навіть на території бувшого СРСР. Англійська мова поступово замінює російську на територіях колишніх радянських республік. Політика деяких 3 них спрямована на дерусифікацію 3 метою позбутися російського фактору, оскільки мова $\epsilon$ джерелом економічного, політичного й культурного впливу. Окрім того, існує ще одна важлива причина зміни статусу російської мови - поки що недостатній рівень розвитку економіки й науки сучасної Росії, в результаті чого російська мова не може конкурувати з англійською з позиції доступу до сучасних знань та інформації. Тому втрачає свої позиції і в країнах Центральної та Східної Свропи, де вона раніше була домінуючою і виступала як лінгва франка.

Наступним чинником, що зумовлює потребу в лінгва франка, $є$ перетворення світового економічного співтовариства в результаті тотальної глобалізації на иілісну економічну систему, об'єднану не лише міжнародним розподілом праці, але й величезними всесвітніми виробничими структурами та структурами збуту, глобальною фінансовою системою й інформаційною мережею планетарного масштабу. Основними ознаками глобалізації є: створення транснаціональних корпорацій; глобалізація фінансових ринків; міжнародна економічна інтеграція; створення міжнародних фінансових і економічних організацій, зокрема МВФ (Міжнародний валютний фонд), ВТО (Всесвітня торгова організація), Всесвітній банк тощо; аутсорсинг - розміщення компаніями частин свого бізнес процесу в країнах 3 дешевшими трудовими витратами тощо. Між вище перерахованими категоріями формується ціла система взаємозв'язків. Для реалізації й обслуговування цієї системи необхідна мова міжнаціонального спілкування. Чим більш інтенсивно розвиваються міжнародні зв'язки та обмін інформацією у глобалізованому світі, тим більша потреба в лінгва франка.

Інтенсифікація міжнародних зв'язків у глобалізованому суспільстві відбувається і за рахунок інформаційно-комунікаційних технологій, які ми також відносимо до чинників, що впливають на вибір мови міжнаціонального спілкування. Їх поява прискорила процес зближення економік і народів, оскільки інформаційна i технологічна революції, інноваційні комунікаційні системи (телебачення, комп'ютери, Інтернет, мобільні телефони, супутники зв'язку, сучасна реактивна авіація тощо) зробили доступною для людей і капіталів найвіддаленіші куточки планети. А це означає, що все більше зростає роль особистих контактів, а отже, вербальної комунікації, зокрема міжнаціональної, яка 
потребує володіння лінгва франка. Розвиток інформаційно-комунікаційних технологій, багато в чому завдяки США, зміцнив ще більше позиції англійської мови як мови міжнаціонального спілкування, оскільки ії знання дає гарантований доступ до новітньої інформації та ринку, зокрема ринку праці. Саме на ринку праці ті, хто володіє англійською мовою, характеризуються високою соціальною мобільністю і користуються першочерговим попитом, тому що в умовах зростання швидкості та кількості інформаційних потоків знання англійської забезпечує можливість швидкого і правильного сприйняття й інтерпретації іншомовного контенту, прийняття правильних рішень, зокрема управлінських на державному рівні тощо. Звідси, стає актуальним твердження, що оволодіння англійською мовою надає певну вигоду, і люди вивчають іiі, щоб забезпечити собі кар'єрне зростання, щоб відповідати часу та суспільному розвитку.

Досить важливим чинником, що зумовлює перетворення англійської мови на лінгва франка $\epsilon$, на нашу думку, і безпосередній результат глобалізації - трудова міграція. Трудова міграція населення, роль якої у світовому розвитку неухильно зростає, перетворюється на невід'ємний складник міжнародної економіки. За даними Міжнародної організації з міграції (МОМ) зараз у світі налічується біля 150 млн. іммігрантів, біженців, легальних мігрантів і тих, хто працює нелегально за кордоном. Варто зауважити у цьому зв'язку, що нелегальна міграція прогресує. За підрахунками Всесвітнього банку кількість нелегальних мігрантів складає 10-15\% від загальної кількості мігрантів у світі. У доповіді Всесвітнього банку «Міграція і грошові перекази», опублікованій наприкінці 2011 року, названі три найбільш привабливі для мігрантів центри - США, Західна Європа і країни Перської затоки.

Зауважими, що згідно з даними Всесвітнього банку, в 2010 році лише $8 \%$ від загальної кількості мігрантів складали біженці із країн Близького Сходу, Північної Африки та Південної Азії. Ситуація з трудовими мігрантами надала підставу дослідникам говорити про них як про один із нових «глобальних класів» [11]. Величезні потоки мігрантів відчувають нагальну потребу в комунікації, спільній мові, за допомогою якої вони могли б контактувати як між собою, так $\mathrm{i} 3$ корінним населенням для отримання роботи та інтеграції в інше суспільство. Саме популярна серед населення різних регіонів світу англійська мова і $є$ на сучасному етапі розвитку суспільства універсальним засобом комунікації для таких категорій людей.

Одним із чинників утвердження англійської мови як мови міжнаціонального спілкування ми вважаємо також і формування транснаціональної інтелектуальної еліти. В соціологічній літературі (В. Іванов, 2006, 3. Бауман, 2008, Р. Інглгард, 2011 та ін.) наголошується на формуванні глобальної соціальної структури $[4 ; 1 ; 5 ;]$. Нині вже існує глобальна еліта, до складу якої входять міжнародні менеджери, юристи, фінансисти, Інтернет-групи та ін. Американський культуролог М. Фезерстоун (M. Featherstone) подає детальну характеристику еліти, що формується, підкреслюючи властиве для іiі представників дистанціювання від традицій відповідного професійного середовища, агресивний стиль поведінки, переважання цінностей технічної компетентності тощо. Вони (представники) не локалізовані в певному національному середовищі, всюди залишаються іноземцями [10].

3 аналізу літератури робимо висновок, що на сучасному етапі суспільного розвитку формуються два види транснаціональної інтелектуальної еліти:

- науковці та фахівці, що утворюють соціокультурну спільність глобального рівня (М. Фезерстоун ). Вони легко перетинають кордони і всюди почуваються комфортно;

- глобальний середній клас, до складу якого входять бізнесмени, фахівці и кваліфіковані робітники тих професій і секторів економіки, які включені до глобальної мережі економічних і професійних зв'язків (менеджери, програмісти тощо). Основними передумовами створення глобального середнього класу науковці називають розповсюдження по всьому світу новітніх технологій і форм організації виробництва, які забезпечують високий матеріальний статус працівників. 
Нова транснаціональна інтелектуальна еліта зазвичай послуговується для спілкування англійською мовою. Це, з одного боку, надає їй можливість почуватися всюди комфортно, з іншого - підвищує статус англійської як мови міжнаціонального спілкування.

Аналіз ситуації з положенням англійської мови показує, що для англомовних країн англійська мова, за твердженням A. Pennycook (1994), є найбільш ходовим товаром, який експортується і користується постійним попитом у будь-якій країні світу.

Віднесення англійської мови до категорії товару, на наше переконання, є також одним iз основних чинників, які сприяють становленню саме цієї мови як мови міжнаціонального спілкування.

Ми не зупиняємося на детальній аргументації цього твердження, оскільки це було вже зроблено в інших публікаціях.

Отже, у рамках реалізації першого завдання нашої статті ми спробували визначити чинники, які впливають на вибір лінгва франка в сучасному глобалізованому суспільстві. Звичайно, ми не претендуємо на повноту переліку. Безумовно, існують ще й інші чинники. Однак і виокремлені нами досить чітко демонструють, що саме економіка глобалізованого світу диктує вибір мови національного спілкування - англійської на сучасному етапі суспільного розвитку. Оскільки ми говоримо про взаємовплив економіки та мови міжнаціонального спілкування, спробуємо проаналізувати як володіння мовою відображається на економіці. 3 цією метою наведемо деякі дані досліджень Свропейської комісії щодо впливу іншомовної компетентності, зокрема володіння англійською як лінгва франка на європейську економіку.

Європейську комісію «Effects on the European Economy of Shortages of Foreign Language Skills in Enterprise (ELAN)» («Наслідки для європейської економіки браку навичок іншомовного спілкування на підприємствах») було створено у грудні 2006 року Головним управлінням освіти і культури Свропейської комісії (Directorate General for Education and Culture of the European Commission) за підтримки Інституту чартерної логістики та транспорту (the Chartered Institute of Logistics and Transport - CILT), Національного Центру Мов Об'єднаного Королівства ( the UK National Centre for Languages) у співпраці 3 Inter Act International i міжнародною командою дослідників. Зокрема, завданням комісії було зібрати практичну інформацію і проаналізувати використання іноземних мов на малих і середніх підприємствах та їх вплив на бізнес-процес. Задля цього було досліджено близько 2000 середніх підприємств-експортерів у 29 європейських країнах (Свросоюзі, EEA (European Economic Area - Свропейській економічній зоні), країнах - кандидатах у члени (С). У результаті досліджень було оприлюднено такі дані:

- Понад чверть експортних компаній у Туреччині зазнали втрат, 25 \% - уРумунії.

- Скандинавські компанії (Фінляндія, Ісландія, Швеція, Данія) оголосили потенційні втрати. Окрім того, ще низка країн задекларувала прямі або потенційні втрати 11\% контрактів: Іспанія, Норвегія, Чехія, Франція та Нідерланди;

- Прямих збитків від втрати контрактів зазнали в цілому $11 \%$ середніх підприємств. У грошовому обчисленні сума складає від 8,100,015 € до 13,500,004 €. Потенційні збитки становлять $16,400,026 €-5,300,010 €$.

Представлено також дані про кількість компаній, які зіткнулися 3 мовним бар'єром, в результаті чого втратили бізнес (у відсотковому співвідношенні): 19 \% компаній в Іспанії; $13 \%$ - у Франції; $10 \%$ - у Німеччині; 21\% - в Англії та Уельсі; 8 \% - у Португалії.

У середньому, втрати бізнесу за три роки склали $325,000 €$. За загальним підрахунком європейська економіка через проблеми з іншомовним спілкуванням щороку втрачає в секторі середнього бізнесу до 100 млрд. € [9].

Як бачимо, втрати величезні. Навіть не вдаючись до аналізу інших даних, поданих комісією, ми вже можемо зробити висновок про збільшення ролі лінгвістичного чинника в сучасній глобалізованій економіці.

Слід також зауважити, що європейські компанії зробили висновок із ситуації, що склалася. Згідно 3 вище зазначеним дослідженням міжнародної комісії понад 48 \% 
підприємств задекларували готовність до мовної перепідготовки персоналу. Однак, більшість середніх та великих компаній надає перевагу залученню працівників, які вже володіють мовою, уникнувши тим самим прямих інвестицій у навчання кадрів.

Викладене вище про взаємовплив мови міжнаціонального спілкування та економіки надає нам підстави розглядати lingua franca як економічну категорію. Ми не оригінальні, стверджуючи це, оскільки іншомовна компетентність вже віднесена до ситуативної категорії, здатної розв'язувати професійні завдання (Костюкова Т., Морозова А., 2011), іншомовна грамотність - до економічної категорії (В. Кузовлєв, 2011) [7; 8].

Поняття іншомовної компетентності, грамотності - базові категорії іншомовної підготовки, яка, у свою чергу є сегментом освіти. Наука й освіта в сучасному світі стали виробничими силами. Перша матеріалізувалась у засобах виробництва. Випереджаючи сучасний розвиток техніки, вона перетворилась на провідну силу матеріального виробництва, генеруючи інновації та змінюючи профіль сучасних суспільств. Друга перетворилась на підсистему суспільства, що забезпечує виробництво і поширення нового наукового знання [2]. Жодна економічна система не може існувати поза виробництвом. Воно пронизує весь господарський процес і $є$ природною умовою людського життя, утворюючи його матеріальну основу. Саме виробництву людство зобов'язане своїм розвитком [3]. Мова ж міжнаціонального спілкування в умовах інтернаціоналізації економік, характерної для глобалізованого світу, нтегруючись у матеріальне виробництво, технічні науки тощо також перетворюється в безпосередню виробничу силу, власне, так само, як наука і освіта, оскільки також причетна до виробництва матеріальних благ. А тому правомірним, з нашої позиції, $є$ віднесення іiї до економічної категорії.

Отже, викладене вище свідчить про нерозривний зв'язок економіки та мови міжнаціонального спілкування в умовах інтернаціоналізації суспільних економік, характерних для епохи глобалізації. Перетворюючись на виробничу силу завдяки інтеграції до матеріального виробництва, яке складає основу будь-якої економіки, мова міжнаціонального спілкування - lingua franca- тим самим набуває статусу економічної категорії.

\section{Література}

1. Бауман 3. Текучая современность / 3. Бауман. - СПб : Питер, 2008. - 240 с. 2. Даулеткериев А. Р. Развитие системы «наука - образование - производство» в эпоху глобализации: социальнофилософские аспекты : автореф. дис . ... канд. философ. наук: специальность 09.00.11. - социальная философия / А. Р. Даулеткериев. - Пятигорск, 2009. - 26 с. З. Вознакевич Е. Е. Дискуссия о новой парадигме гуманитарных наук / Е. Е. Вознакевич // Вопросы философии. - 2007. - № 12. - С. 171175. 4. Иванов В. Г. Транснациональные элиты: концептуальное поле исследования : автореф. дис. ... канд. полит. наук : 23.00 .01 / В. Г. Иванов. - М., 2006. - 26 с. 5. Инглхарт Р., Вельцель К. Модернизация, культурные изменения и демократия: Последовательность человеческого развития / Р. Инглхарт, К. М. Вельцель - М. : Новое издательство, 2011.- 464 с. 6. Интрилигейтор М. Глобализация как источник международных конфликтов и обострения конкуренции / М. Интрилигейтор - [Электронный ресурс]. - Режим доступа: http: // www. ptpu. ru / issues/ 6_98/6_6_98. htm 7. Костюкова Т. А. Развитие иноязычной коммуникативной компетентности студентов неязыковых вузов: монография / Т. А. Костюкова, А. Л. Морозова. - Томск: Изд-во Томского политехнического университета, 2011.- 119 с. 8. Кузовлев В. П. Английский язык. Рабочие программы (5-9 классы): [пособие для учителей общеобразовательных учреждений] / В. П. Кузовлев, Н. М. Лапа, Э. Ш. Перегудова. - М. : Просвещение, 2011. - 214 с. 9. Effects on the European Economy of Shortages of Foreign Language Skills in Enterprise (ELAN): December 2006. - pp. 1 - 79. http://ec.europa.eu/education/policies/lang/doc/elan_en.pdf 10. Featherstone M. Problematizing Global Knowledge and the New Encyclopaedia Project. An Introduction /M. Featherstone, C. Venn // Theory, Culture\& Society, 2006. - P. 1-20. 11. Fischer S. Globalization: Valid Concerns? http://www.imf.org/extemal/np/speeches/2000/082600/htm 12. Sassen S. New Global Classes: Implications for Politics // The New Egalitarianism / Ed. A. Giddens, P. Diamond. Cambridge; Maldon: Polity Press, 2005. - P. 143-153. 